\title{
ANTIFUNGAL ACTIVITY OF ESSENTIAL OILS OF Myrcia ovata CHEMOTYPES AND THEIR MAJOR COMPOUNDS ON PHYTOPATHOGENIC FUNGI
}

\author{
ATIVIDADE ANTIFÚNGICA DOS ÓLEOS ESSENCIAIS DE QUIMIOTIPOS DE \\ Myrcia ovata E SEUS COMPOSTOS MAJORITÁRIOS SOBRE FUNGOS \\ FITOPATOG $\hat{E} N I C O S$
}

\section{Taís Santos SAMPAIO ${ }^{1}$; Arie Fitzgerald BLANK ${ }^{2 *}$; Paulo Roberto GAGLIARDI ${ }^{2}$; Alberto WISNIEWSKI JR ${ }^{3}$; Maria de Fátima ARRIGONI-BLANK²; Daniela Aparecida de Castro NIZIO'; Mércia Freitas ALVES ${ }^{4}$; Alberto Ferreira de NASCIMENTO JUNIOR ${ }^{5}$}

\begin{abstract}
1. Doutora em Biotecnologia, Universidade Federal de Sergipe - UFS, São Cristóvão, SE, Brasil; 2. Professor do Departamento de Engenharia Agronômica, Universidade Federal de Sergipe, São Cristóvão, Brasil. arie.blank@gmail.com; 3. Professor do Departamento de Engenharia Química, Universidade Federal de Sergipe, São Cristóvão, Brasil; 4. Pós-doutoranda em Agronomia da Universidade

Federal de Uberlândia, Campus Umuarama, Uberlândia, MG, Brasil; 5. Mestrando em Agricultura e Biodiversidade, UFS, São Cristóvão, SE, Brasil.
\end{abstract}

\begin{abstract}
This work evaluated the antifungal activity of essential oils of Myrcia ovata chemotypes (MYRO-175, MYRO-156, MYRO-154, MYRO-165, and MYRO-015) and their major compounds (linalool, geraniol, citral, and (E)-nerolidol) on the phytopathogenic fungi Fusarium pallidoroseum (which causes melon postharvest rot) and Colletotrichum musae (which causes anthracnose in banana). The essential oils were obtained by hydrodistillation and analyzed by GCMS/FID. To evaluate the antifungal activity, the essential oils and their major compounds were tested at different concentrations $(0.1 ; 0.3 ; 0.4 ; 0.5 ; 0.7 ; 1.0 ; 3.0$, and 5.0 $\mathrm{mL} / \mathrm{L})$. The major compounds found in the essential oils were nerolic acid, linalool, geraniol, citral, and $(E)$ nerolidol. The essential oils of the plants MYRO-154, MYRO-165, and MYRO-015 had the minimum inhibitory concentration (MIC) $(0.3 \mathrm{~mL} / \mathrm{L})$ for $F$. pallidoroseum and the lowest minimum fungicidal concentration (MFC) $(0.7 \mathrm{~mL} / \mathrm{L})$, for $C$. musae. Geraniol and citral had the lowest MFC $(0.5 \mathrm{~mL} / \mathrm{L})$ for the two fungi tested. For $F$. pallidoroseum, the essential oils of the chemotypes were more effective than their major compounds. Conversely, the major compounds geraniol of the chemotype MYRO-156 (74.37\%) and citral were more effective than their respective essential oils for $C$. musae. $(E)$-nerolidol and geraniol of the chemotype MYRO-015 (33.15\%) were responsible for the antifungal activity of the essential oils of their respective chemotypes.
\end{abstract}

KEYWORDS: Myrcia ovata. Volatile compounds. Fusarium pallidoroseum. Colletotrichum musae.

\section{INTRODUCTION}

Fungi diseases are one of the main causes of fruit losses at the post-harvest stage. The effects of these phytopathogens are also the main reasons for changes in appearance, odor, taste, texture, and reduction of nutritional values, leading to the depreciation of the commercial value of these products (KFOURY et al., 2016). The phytopathogen Fusarium pallidoroseum is one of the causative agents of melon postharvest rot, and Colletotrichum musae is the main responsible for anthracnose in banana. These fungi infect the plant through lesions or injuries in the cutting area of the peduncle during harvest (BOUBAKER et al., 2016).

The fungus $F$. pallidoroseum is commonly associated with melon postharvest rot and is found in the soil, in plant remains, in tropical and subtropical regions (LOKESH et al., 2008; GONDIM et al., 2008). The infection occurs through natural cracks in the peduncle abscission zone during harvest, and the pathogenesis develops at the post-harvest stage. C. musae is responsible for losses of up to $40 \%$ in banana production due to anthracnose, which is characterized by dark-brown to black, sunken spots on the peel, affecting commercialization and in natura consumption (PESSOA et al., 2007).

Synthetic fungicides have been used to control these fungi. However, the strong pressure of the society for certification seals and food safety has prevented the use of these chemicals in fungi control. The need to create safe and biodegradable alternatives, such as natural fungicides based on 
plant essential oils, have emerged due to the consumer's demand for synthetic chemical-free products. Another reason is the fact that phytopathogens develop resistance as a result of excessive use of fungicides (BAKKALI et al., 2008).

Myrcia ovata Cambess. presents excellent antifungal potential (SAMPAIO et al., 2016; BLANK et al., 2015). The species belongs to the Myrtaceae family and is a shrub that produces essential oils with other biological activities, such as anti-inflammatory, antinociceptive, analgesic, antibacterial, and insecticide (SANTOS et al., 2014; QUINTANS-JÚNIOR et al., 2011; CANDIDO et al., 2010; LIMA et al., 2011). The phytochemical profile of its essential oils is characterized by the presence of the compounds nerolic acid, linalool, geraniol, citral, and $(E)$-nerolidol (SAMPAIO et al., 2016). Thus, this study aimed to evaluate the antifungal activity of the essential oil of $M$. ovata Cambess. chemotypes and their major compounds linalool, geraniol, citral, and (E)-nerolidol against the fungi $F$. pallidoroseum and $C$. musae.

\section{MATERIAL AND METHODS}

\section{Plant material and essential oil extraction}

The essential oils of the chemotypes MYRO-175, MYRO-156, MYRO-154, MYRO-165, and MYRO-015 were characterized by Sampaio et al. 2016 (Table 1). Leaves were collected in the municipality of Japaratuba, in the state of Sergipe, northeastern Brazil. Plants were manually defoliated and dried in a forced-air circulation oven at $40{ }^{\circ} \mathrm{C}$ for five days. The essential oil was extracted by hydrodistillation in a modified Clevenger apparatus using $50 \mathrm{~g}$ of dry leaf for 140 minutes (EHLERT et al., 2006). The essential oils were collected and stored in amber flasks at $-20{ }^{\circ} \mathrm{C}$ until chemical composition analysis. The compounds linalool, geraniol, citral, and $(E)$-nerolidol were purchased from Sigma-Aldrich Corporation.

Table 1. Identification and origin of Myrcia ovata plants.

\begin{tabular}{|c|c|c|c|}
\hline Code & Place of origin & Geographic coordinates & $\begin{array}{l}\text { \# Voucher } \\
\text { UFS Herbarium }\end{array}$ \\
\hline MYRO- 175 & Japaratuba-SE & $10^{\circ} 38^{\prime} 44,8^{\prime} \mathrm{S} ; 36^{\circ} 52^{\prime} 17,7^{\prime} \mathrm{W}$ & 33.827 \\
\hline MYRO-156 & Japaratuba-SE & $10^{\circ} 37^{\prime} 38,7^{\prime \prime} \mathrm{S} ; 36^{\circ}$ 53’19,6”W & 30.877 \\
\hline MYRO-154 & Japaratuba-SE & $10^{\circ} 37^{\prime} 38,1^{\prime \prime} \mathrm{S} ; 36^{\circ} 53^{\prime} 16,8^{\prime \prime} \mathrm{W}$ & 30.876 \\
\hline MYRO-165 & Japaratuba-SE & $10^{\circ} 38^{\prime} 45,3 ” \mathrm{~S} ; 36^{\circ} 52^{\prime} 17,4^{\prime \prime} \mathrm{W}$ & 30.173 \\
\hline MYRO-015 & Japaratuba-SE & $10^{\circ} 33^{\prime} 45,5^{\prime \prime} \mathrm{S} ; 36^{\circ} 52^{\prime} 16,4^{\prime \prime} \mathrm{W}$ & 35.723 \\
\hline
\end{tabular}

\section{Chromatographic analyses}

The analysis of the chemical composition of the essential oils was carried out using a GCMS/FID (QP2010 Ultra, Shimadzu Corporation, Kyoto, Japan), equipped with an autosampler AOC20i (Shimadzu), as described by SAMPAIO et al. (2016).

\section{Antifungal activity}

Pure cultures of the fungi $F$. pallidoroseum and $C$. musae were obtained from the Phytopathology Laboratory of the Federal University of Sergipe. The antifungal activity of the essential oils was evaluated in a contact trial based on mycelial growth inhibition (CHANG et al., 2008).

The experiment consisted of a completely randomized design (CRD) with three replications in each treatment. The essential oils were tested at the concentrations of $0.1,0.3,0.4,0.5,0.7$, and 1.0 $\mathrm{mL} / \mathrm{L}$, and the major compounds were tested at the concentrations of $0.1,0.3,0.4,0.5,0.7,1.0,3.0$, and $5.0 \mathrm{~mL} / \mathrm{L}$. The substances were solubilized in $1 \%$ dimethyl sulfoxide (DMSO, Sigma-Aldrich) and homogenized in sterile PDA culture medium (Potato Dextrose Agar, HIMEDIA). Solutions were then poured into $9.0 \mathrm{~cm}$ diameter Petri dishes, and each dish was inoculated in the center with a $7.0 \mathrm{~mm}$ diameter disk of the fungus culture.

Petri dishes were stored in a B.O.D chamber at $22 \pm 3{ }^{\circ} \mathrm{C}$, with a 12-hour photoperiod. Petri dishes containing only the PDA culture medium and PDA + DMSO were used as controls. The evaluations were performed by measuring the mycelial diameter (mean of two diametrically opposite measures), using a pachymeter. At 96 hours after incubation, the mycelial discs of the concentrations showing no visible growth were transferred to Petri dishes containing only the PDA culture medium and incubated for another 96 hours. At the end of the evaluations, the percentage of mycelial growth inhibition (PMGI) of the fungus of the treatments was calculated, in relation to the control containing only PDA and the fungus, by the formula:

$$
(\%) \text { Inibition }=\frac{\mathrm{dc}-\mathrm{dt}}{\mathrm{dc}} \times 100
$$


Antifungal activity...

where $\mathrm{dc}=$ is the diameter of the control, and $\mathrm{dt}=$ is the diameter of the treatment. The lowest growth concentration after transferring to the medium without essential oil was considered as minimum inhibitory concentration (MIC). The lowest concentration at which no growth was observed after transferring to the medium without essential oil was considered as minimum fungicidal concentration (MFC).

\section{Statistical analysis}

The means of the percentage of mycelial growth inhibition with the respective standard error of mean were obtained with the Graph Pad Prism® software (mean \pm SEM).

\section{RESULTS AND DISCUSSION}

Table 2. Chemical composition of the essential oil of Myrcia ovata chemotypes.

\begin{tabular}{|c|c|c|c|c|c|c|}
\hline Compounds & IRRI & $\begin{array}{l}\text { MYRO- } \\
175\end{array}$ & MYRO-156 & $\begin{array}{l}\text { MYRO- } \\
154\end{array}$ & MYRO-165 & MYRO-015 \\
\hline$\alpha$-thujene & 924 & 0.14 & - & - & - & - \\
\hline$\alpha$-pinene & 932 & 0.82 & 0.30 & - & - & - \\
\hline$\beta$-pinene & 974 & 0.81 & 0.29 & 0.32 & - & - \\
\hline 1,8-dehydro-cineol & 988 & - & - & 0.31 & - & - \\
\hline Myrcene & 988 & 0.47 & - & - & - & - \\
\hline$\alpha$-terpinene & 1014 & 0.20 & - & - & - & - \\
\hline p-cimene & 1020 & 0.21 & 0.23 & - & - & - \\
\hline limonene & 1024 & 0.56 & 0.36 & 0.15 & - & - \\
\hline 1,8-cineol & 1026 & 8.68 & 1.38 & 0.75 & 0.45 & 2.61 \\
\hline$\gamma$-terpinene & 1054 & 0.42 & 0.24 & - & - & - \\
\hline (Z)-linalool oxide & 1067 & 0.25 & - & - & - & 0.11 \\
\hline$(E)$ - linalool oxide & 1084 & 0.32 & - & - & - & 0.12 \\
\hline linalool & 1905 & 14.97 & 7.56 & 0.53 & 0.78 & 10.58 \\
\hline Isopulegol & 1445 & - & - & 2.30 & - & - \\
\hline Citronelal & 1448 & - & - & 9.19 & - & - \\
\hline Iso-isopulegol & 1155 & - & - & 1.40 & - & - \\
\hline 2-pinen-4-ol & 1158 & - & - & 0.80 & - & - \\
\hline$\alpha$-terpineol & 1162 & - & - & - & - & - \\
\hline Neoiso-isopulegol & 1167 & - & - & 0.35 & - & - \\
\hline$\alpha$-felandren-8-ol & 1170 & - & - & 0.76 & - & - \\
\hline Terpinen-4-ol & 1174 & 1.17 & 1.41 & - & 0.31 & 0.35 \\
\hline$(E)$-isocitral & 1177 & - & - & 1.42 & - & - \\
\hline$\alpha$-terpineol & 1186 & 4.60 & 2.24 & 1.01 & 0.50 & 1.43 \\
\hline Citronelol & 1223 & - & - & 3.27 & - & - \\
\hline Neral & 1235 & 0.23 & 0.11 & 28.39 & 0.27 & 0.48 \\
\hline Geraniol & 1249 & 1.61 & 74.37 & 1.33 & 1.11 & 33.15 \\
\hline Methyl citronelate & 1257 & - & - & - & 2.78 & - \\
\hline Geranial & 1264 & 1.21 & 1.93 & 40.10 & 0.58 & 2.47 \\
\hline Methyl nerolate & 1280 & - & - & - & 1.57 & 2.24 \\
\hline Methyl Geranate & 1322 & - & - & - & - & - \\
\hline Nerolic acid & 1347 & 52.61 & - & - & 47.20 & 31.65 \\
\hline Geranic acid & 1372 & - & - & - & 1.59 & 0.71 \\
\hline$\alpha$-copaene & 1374 & - & - & - & - & - \\
\hline Geranyl Acetate & 1379 & 1.39 & - & - & - & 1.78 \\
\hline
\end{tabular}

SAMPAIO, T. S. et al.

Essential oils of $M$. ovata Cambess. chemotypes were characterized by the presence of oxygenated monoterpenes and sesquiterpenes (Table 2). The chemotype MYRO-175 had 1,8-cineol (8.68\%), linalool (14.97\%), $\alpha$-terpineol (4.60\%), and nerolic acid (52.61\%) as major compounds. The chemotype MYRO-156 showed linalool (7.56\%) and geraniol $(74.37 \%)$ as major compounds. The chemotype MYRO-154 had citronellal (9.19\%), neral $(28.39 \%)$, and geranial $(40.10 \%)$ as major compounds. The chemotype MYRO-165 showed nerolic acid (47.20\%), (E)-nerolidol (26.97\%), and (2Z,6E)-farnesol (7.91\%) as major compounds. The chemotype MYRO-015 had linalool (10.58\%), geraniol (33.15\%), nerolic acid $(31.65 \%)$, and $(E)$ nerolidol (4.63\%) as major compounds. 
SAMPAIO, T. S. et al.

\begin{tabular}{|c|c|c|c|c|c|c|}
\hline$(E)$-caryophyllene & 1417 & 0.88 & 0.74 & 0.51 & 1.69 & 0.77 \\
\hline$\alpha$ - $(E)$-bergamotene & 1432 & - & 0.10 & - & - & 0.10 \\
\hline (Z)- $\beta$-farnesene & 1440 & - & - & - & 0.22 & - \\
\hline$\alpha$-humulene & 1452 & 0.14 & 0.11 & - & 0.33 & 0.11 \\
\hline$(E)$ - $\beta$-farnesene & 1454 & - & - & - & - & 0.41 \\
\hline$\beta$-santalene & 1457 & - & - & - & & - \\
\hline$\beta$-selinene & 1489 & 3.61 & 0.94 & 1.61 & - & 1.75 \\
\hline Neryl Isobutonoate & 1490 & 0.18 & - & - & - & - \\
\hline$\alpha$-selinene & 1498 & 3.51 & 0.91 & 1.43 & - & 1.54 \\
\hline (Z)- $\alpha$-bisabolene & 1506 & - & - & - & 0.14 & - \\
\hline (E)-nerolidol & 1561 & - & - & - & 26.97 & 4.63 \\
\hline Spathulenol & 1577 & 0.25 & 0.17 & 0.20 & 0.81 & 0.52 \\
\hline Caryophylene oxide & 1582 & 0.66 & 1.47 & 0.93 & 1.57 & 0.63 \\
\hline Humulene oxide & 1626 & - & 0.18 & - & - & - \\
\hline$\beta$-bisabolol & 1674 & - & - & - & - & 0.81 \\
\hline$\alpha$-bisabolol & 1690 & - & - & - & 0.45 & \\
\hline (Z)- $\alpha$-trans-bergamotol & 1690 & - & 3.04 & - & - & - \\
\hline$(2 E, 6 Z)$-farnesol & 1714 & - & - & 1.30 & 0.11 & - \\
\hline$(2 Z, 6 E)$-farnesal & 1715 & - & - & 0.41 & - & - \\
\hline$(2 Z, 6 E)$-farnesol & 1722 & - & - & 0.44 & 7.91 & - \\
\hline$(2 E, 6 E)$-farnesal & 1740 & - & - & - & 0.57 & - \\
\hline$(2 E, 6 E)$-farnesol & 1742 & - & - & 0.55 & - & 0.94 \\
\hline
\end{tabular}

RRIl: Relative Retention Index - literature (Adams, 2007).

All the chemotypes of the essential oil of $M$. ovata exhibited antifungal activity against $F$. pallidoroseum and $C$. musae, highlighting the chemotypes represented by the major compounds geraniol, citral, and (E)-nerolidol (Table 3 and 5).

The percentage of mycelial growth inhibition (PMGI) ranged from 73.52 to $88.52 \%$ at the lowest essential oil concentration $(0.1 \mathrm{~mL} / \mathrm{L})$ against $F$. pallidoroseum, reaching $100 \%$ inhibition at concentrations of $0.3 \mathrm{~mL} / \mathrm{L}$ for all chemotypes, except for MYRO-156, whose PMGI ranged from 74.63 to $92.41 \%$ at concentrations of 0.1 to 0.4 $\mathrm{mL} / \mathrm{L}$, respectively (Table 3; Figure 1A). For $C$. musae, the PMGI ranged from 75.00 to $89.35 \%$ at the lowest essential oil concentration $(0.1 \mathrm{~mL} / \mathrm{L})$, reaching $100 \%$ inhibition at concentrations of 0.3 $\mathrm{mL} / \mathrm{L}$ for all chemotypes, except for MYRO-175, whose PMGI ranged from to 77.31 to $86.67 \%$ at concentrations of 0.1 and $0.3 \mathrm{~mL} / \mathrm{L}$, respectively (Table 3, Figure 1B).

Table 3. Percentage of mycelial growth inhibition (mean \pm SEM) of the fungi $F$. pallidoroseum (FP) and $C$. musae $(\mathrm{CM})$ in function of the concentrations $(\mathrm{mL} / \mathrm{L})$ of the essential oils of five M. ovata chemotypes.

\begin{tabular}{lll}
\hline & Mycelial Growth Inhibition (\%) & \\
\hline Concentration (mL/L) & F. pallidoroseum & C. musae \\
\hline MYRO-175 & & \\
\hline 0.1 & $88.52 \pm 0.86$ & $77.31 \pm 1.91$ \\
0.3 & $100.0 \pm 0.00$ & $86.67 \pm 1.67$ \\
0.4 & $100.0 \pm 0.00$ & $100.0 \pm 0.00$ \\
0.5 & $100.0 \pm 0.00$ & $100.0 \pm 0.00$ \\
\hline MYRO-156 & \\
\hline 0.1 & $74.63 \pm 2.10$ & $75.00 \pm 1.30$ \\
0.3 & $85.09 \pm 3.02$ & $100.0 \pm 0.00$ \\
0.4 & $92.41 \pm 0.62$ & $100.0 \pm 0.00$ \\
0.5 & $100.0 \pm 0.00$ & $100.0 \pm 0.00$ \\
0.7 & $100.0 \pm 0.00$ & $100.0 \pm 0.00$ \\
\hline MYRO-154 & & $76.11 \pm 1.11$ \\
\hline 0.1 & $73.52 \pm 1.73$ & $100.0 \pm 0.00$
\end{tabular}




\begin{tabular}{lll}
\hline MYRO-165 & & \\
\hline 0.1 & $73.70 \pm 1.60$ & $89.35 \pm 1.05$ \\
0.3 & $100.0 \pm 0.00$ & $100.0 \pm 0.00$ \\
0.4 & $100.0 \pm 0.00$ & $100.0 \pm 0.00$ \\
\hline MYRO-015 & & \\
\hline 0.1 & $78.89 \pm 0.74$ & $78.52 \pm 0.31$ \\
0.3 & $100.0 \pm 0.00$ & $100.0 \pm 0.00$ \\
0.4 & $100.0 \pm 0.00$ & $100.0 \pm 0.00$ \\
\hline
\end{tabular}

SEDM $=$ standard error of mean $(n=3)$.

For the major compounds, the PMGI varied from 49.63 to $61.30 \%$ at the lowest concentration (equivalent to $0.1 \mathrm{~mL} / \mathrm{L}$ of essential oil) for $F$. pallidoroseum. For this same fungus, at the lowest concentration $(0.1 \mathrm{~mL} / \mathrm{L}$ of essential oil), linalool, one of the major compounds of the essential oil of chemotype MYRO-175, showed lower toxicity $(59.26 \%)$ than its essential oil (88.52\%), with maximum PMGI at concentrations higher than 3.0 $\mathrm{mL} / \mathrm{L}$ (Table 3 and 4).

Geraniol, found in the plants MYRO-156 $(74.37 \%)$ and MYRO-015 (33.15\%), caused maximum inhibition at the same concentration (equivalent to $0.4 \mathrm{~mL} / \mathrm{L}$ of essential oil), against $F$. pallidoroseum. At the concentration of $0.3 \mathrm{~mL} / \mathrm{L}$, citral caused effective mycelial growth inhibition (68.06\%), while its essential oil (MYRO-154) caused $100 \%$ inhibition. The sesquiterpene alcohol (E)-nerolidol caused $65.74 \%$, while its essential oil
(MYRO-165) led to $100 \%$ inhibition at the same concentration (Table 4).

For the major compounds, against $C$. musae, the PMGI ranged from 49.26 to $92.96 \%$ at the lowest concentration, reaching $100 \%$ inhibition at concentrations of $0.3 \mathrm{~mL} / \mathrm{L}$, for geraniol ${ }^{\mathrm{b}}$ and citral. At the lowest concentration $(0.1 \mathrm{~mL} / \mathrm{L})$, linalool had lower toxicity $(49.26 \%)$ than its essential oil (77.31\%), with a maximum PMGI at concentrations higher than $1.0 \mathrm{~mL} / \mathrm{L}$. Geraniol caused maximum inhibition at the concentration of $0.3 \mathrm{~mL} / \mathrm{L}$ for MYRO-156 and $0.4 \mathrm{~mL} / \mathrm{L}$ for MYRO-015. At the concentration of $0.1 \mathrm{~mL} / \mathrm{L}$, citral was more effective than its essential oil (MYRO-154), causing effective mycelial growth inhibition of $89.63 \%$ against $76.11 \%$ of its essential oil. (E)-nerolidol had $80.19 \%$ inhibition against $89.35 \%$ of its essential oil (MYRO-165) at the same concentration, with no great variations in PMGI values (Table 3 and 4; Figure 2B').

Table 4. Percentage of mycelial growth inhibition (mean \pm SEM) of the fungi $F$. pallidoroseum and $C$. musae in function of the concentrations of the major compounds linalool, geraniol ${ }^{\mathrm{b}}$, citral, $(E)$-nerolidol, and geraniol ${ }^{c}$.

\begin{tabular}{|c|c|c|c|}
\hline \multicolumn{4}{|c|}{ Major $\quad$ compound Equivalence in essential Mycelial Growth Inhibition (\%) } \\
\hline concentrations $(\mathrm{mL} / \mathrm{L})$ & oil $\left(\mu \mathrm{L} \mathrm{mL} L^{-1}\right)$ & F. pallidoroseum & C. musae \\
\hline Linalool & MYRO-175 & & \\
\hline 0.0150 & 0.1 & $59.26 \pm 0.86$ & $49.26 \pm 0.25$ \\
\hline 0.0449 & 0.3 & $61.85 \pm 0.86$ & $53.98 \pm 1.73$ \\
\hline 0.0599 & 0.4 & $73.89 \pm 0.74$ & $58.89 \pm 0.74$ \\
\hline 0.0749 & 0.5 & $84.44 \pm 0.74$ & $73.24 \pm 0.25$ \\
\hline 0.1048 & 0.7 & $93.52 \pm 4.32$ & $85.56 \pm 1.11$ \\
\hline 0.1497 & 1.0 & $94.44 \pm 0.00$ & $100.0 \pm 0.00$ \\
\hline 0.4491 & 3.0 & $100.0 \pm 0.00$ & $100.0 \pm 0.00$ \\
\hline 0.7485 & 5.0 & $100.0 \pm 0.00$ & $100.0 \pm 0.00$ \\
\hline Geraniol $^{\mathrm{b}}$ & MYRO-156 & & \\
\hline 0.0744 & 0.1 & $51.94 \pm 1.85$ & $92.96 \pm 0.25$ \\
\hline 0.2231 & 0.3 & $60.74 \pm 0.31$ & $100.0 \pm 0.00$ \\
\hline 0.2975 & 0.4 & $100.0 \pm 0.00$ & $100.0 \pm 0.00$ \\
\hline 0.3719 & 0.5 & $100.0 \pm 0.00$ & $100.0 \pm 0.00$ \\
\hline Citral & MYRO-154 & & \\
\hline 0.0685 & 0.1 & $58.15 \pm 0.99$ & $89.63 \pm 0.25$ \\
\hline
\end{tabular}




\begin{tabular}{llll}
\hline 0.2055 & 0.3 & $68.06 \pm 1.48$ & $100.0 \pm 0.00$ \\
0.2740 & 0.4 & $74.54 \pm 1.23$ & $100.0 \pm 0.00$ \\
0.3425 & 0.5 & $90.00 \pm 0.56$ & $100.0 \pm 0.00$ \\
0.4794 & 0.7 & $100.0 \pm 0.00$ & $100.0 \pm 0.00$ \\
0.6849 & 1.0 & $100.0 \pm 0.00$ & $100.0 \pm 0.00$ \\
\hline$(E)$-nerolidol & MYRO- 165 & & $80.19 \pm 0.62$ \\
\hline 0.0517 & 0.1 & $61.30 \pm 0.49$ & $85.00 \pm 0.74$ \\
0.1550 & 0.3 & $65.74 \pm 0.49$ & $89.26 \pm 0.62$ \\
0.2067 & 0.4 & $74.63 \pm 0.99$ & $100.0 \pm 0.00$ \\
0.2584 & 0.5 & $88.67 \pm 2.40$ & $100.0 \pm 0.00$ \\
0.3617 & 0.7 & $91.85 \pm 0.49$ & $100.0 \pm 0.00$ \\
0.5167 & 1.0 & $100.0 \pm 0.00$ & $100.0 \pm 0.00$ \\
1.5501 & 3.0 & $100.0 \pm 0.00$ & \\
\hline Geraniol & MYRO-015 & & $52.04 \pm 0.25$ \\
0.0332 & 0.1 & $49.63 \pm 0.31$ & $100.0 \pm 0.00$ \\
0.0995 & 0.3 & $61.57 \pm 0.43$ & $100.0 \pm 0.00$ \\
0.1326 & 0.4 & $100.0 \pm 0.00$ & \\
0.1658 & 0.5 & $100.0 \pm 0.00$ & \\
\hline
\end{tabular}

$\mathrm{SEM}=$ standard error of mean $(\mathrm{n}=3)$. Geraniol $^{\mathrm{b}}(\mathrm{MYRO} 156)$. Geraniol $^{\mathrm{c}}$ (MYRO 015).
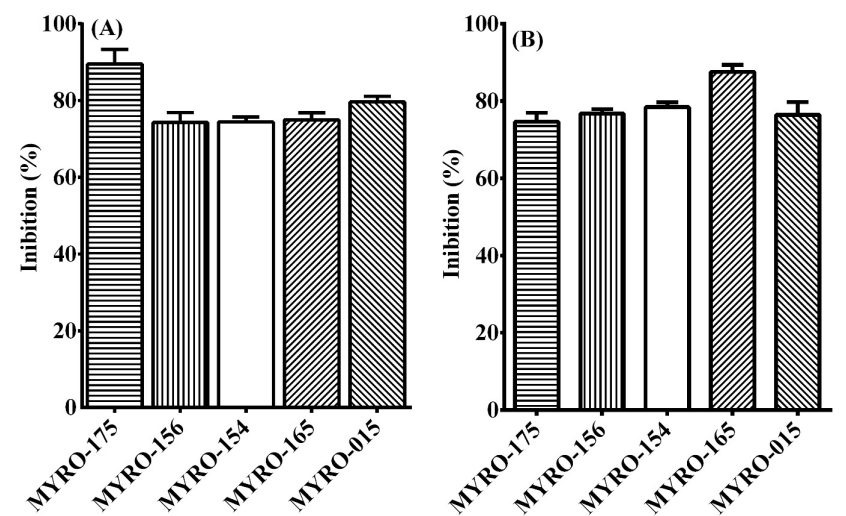

Figure 1. Comparison between the percentage of mycelial growth inhibition (mean \pm SEM) of the fungi $F$. pallidoroseum (A) and C. musae (B) in function of the essential oils $(0.1 \mathrm{~mL} / \mathrm{L})$ of five $M$. ovata chemotypes.
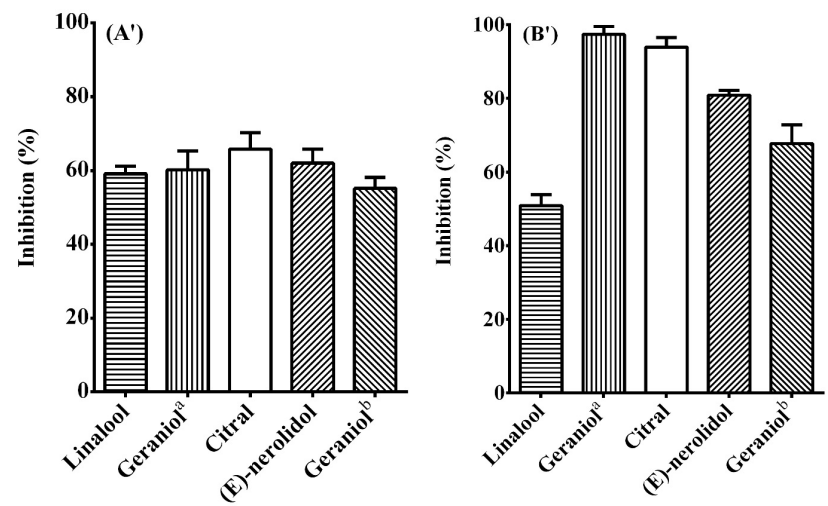

Figure 2. Comparison between the percentage of mycelial growth inhibition (mean \pm SEM) of the fungi $F$. pallidoroseum (A') and C. musae (B') in function of the major compounds of five chemotypes of $M$. ovata, tested at a concentration equivalent to $0.1 \mathrm{~mL} / \mathrm{L}$ of essential oil; (linalool; MYRO-175), (geraniola; MYRO-156), (citral; MYRO-154), [ (E)-nerolidol; MYRO-165], (geraniol'b; MYRO015). 
Regarding the essential oils for both fungi, the Minimum Inhibitory Concentration (MIC) and Minimum Fungicidal Concentration (MFC) were 0.3 and $0.7 \mathrm{~mL} / \mathrm{L}$, respectively, for all chemotypes tested, except for the essential oil of MYRO- 156, with MIC of $0.5 \mathrm{~mL} / \mathrm{L}$ (for $F$. pallidoroseum), and MYRO-175, with MIC of $0.4 \mathrm{~mL} / \mathrm{L}$ (for C. musae); and MYRO-015 and MYRO-175 with MFC of 1.0 $\mathrm{mL} / \mathrm{L}$ for $F$. pallidoroseum and $C$. musae, respectively. Among the major compounds for both fungi, geraniol (MYRO-156 and MYRO-015), citral (MYRO-154), and (E)-nerolidol were the most effective, with MIC values ranging from 0.4 to 1.0 $\mathrm{mL} / \mathrm{L}$, and MFC values varying from 0.5 to 3.0 $\mathrm{mL} / \mathrm{L}$. Linalool presented the highest MIC (3.0 $\mathrm{mL} / \mathrm{L}$ ) and MFC (5.0 mL/L), for both fungi (Table 5).

Table 5. Minimum Inhibitory Concentration (MIC) and Minimum Fungicide Concentration (MFC) in function of the concentrations (mL/L) of the essential oils of M. ovata chemotypes and their major compounds on F. pallidoroseum (FP) and C. musae (CM).

\begin{tabular}{|c|c|c|c|c|}
\hline \multirow[t]{2}{*}{ Chemotypes } & \multirow{2}{*}{$\begin{array}{l}\text { Minimum } \\
\text { concentration } \mathrm{mL} / \mathrm{L} \\
\mathrm{FP}\end{array}$} & \multirow{2}{*}{$\begin{array}{c}\text { inhibitory } \\
\text { CM }\end{array}$} & \multicolumn{2}{|c|}{ Minimum Fungicide Concentration (mL/L) } \\
\hline & & & FP & $\mathrm{CM}$ \\
\hline MYRO-175 & 0.3 & 0.4 & 0.7 & 1.0 \\
\hline MYRO-156 & 0.5 & 0.3 & 0.7 & 0.7 \\
\hline MYRO-154 & 0.3 & 0.3 & 0.7 & 0.7 \\
\hline MYRO-165 & 0.3 & 0.3 & 0.7 & 0.7 \\
\hline MYRO-015 & 0.3 & 0.3 & 1.0 & 0.7 \\
\hline Linalool & 3.0 & 1.0 & 5.0 & 3.0 \\
\hline Geraniol $^{\mathrm{a}}$ & 0.4 & 0.3 & 0.5 & 0.5 \\
\hline Citral & 0.7 & 0.3 & 1.0 & 0.5 \\
\hline$(E)$-nerolidol & 1.0 & 0.5 & 3.0 & 0.7 \\
\hline Geraniol $^{\mathrm{b}}$ & 0.4 & 0.4 & 0.5 & 0.7 \\
\hline
\end{tabular}

SEM = standard error of mean $(n=3)$. Geraniol ${ }^{\mathrm{a}}\left(\right.$ MYRO 156). Geraniol ${ }^{\mathrm{b}}($ MYRO 015).

In relation to the specificity of the essential oils and/or major compounds against the microorganisms studied, all the essential oils were more toxic than their major compounds for $F$. pallidoroseum, whereas the essential oil of the chemotypes MYRO-175, MYRO-165, and MYRO-

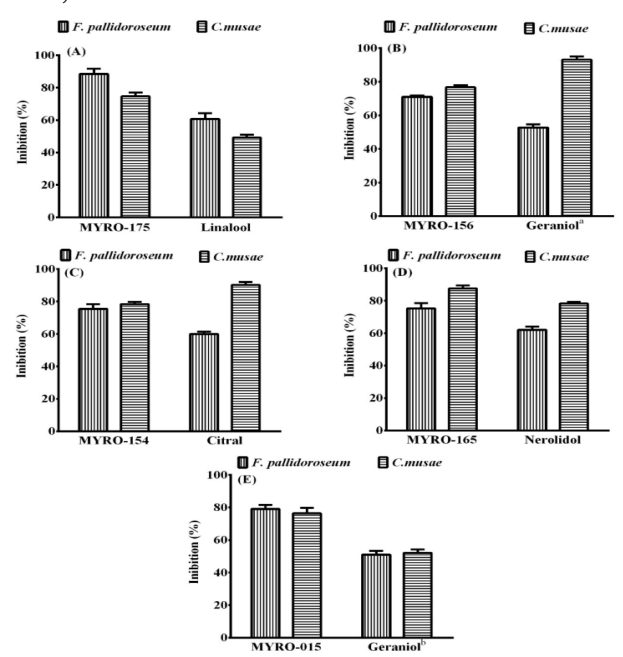

015 had more effective mycelial growth inhibition on C.musae. Moreover, geraniol and citral were more efficient in the control of C.musae than their essential oil of origin (Figure 3).

Figure 3. Comparison between the percentage of mycelial growth inhibition (mean \pm SEM) of the fungi $F$. pallidoroseum (FP) and C. musae (CM) in function of the essential oils of five chemotypes of $M$. ovata (at a concentration of $0.1 \mathrm{~mL} / \mathrm{L}$ ) and their major compounds (at a concentration equivalent to $0.1 \mathrm{~mL} / \mathrm{L}$ of essential oil): (MYRO-175; linalool), (MYRO-156; geraniola), (MYRO-154; citral), [MYRO-165; (E)-nerolidol], and (MYRO-015; geraniol $^{\mathrm{b}}$ ). 
The use of plant essential oils as microbiological agents has confirmed the existence of significant biological activities, and some of them have received significant attention due to their use in the control of phytopathogenic fungi that cause diseases in fruit species of economic interest. Some plants of the family Myrtaceae are known for their antimicrobial activity, mainly fungicides (SAMPAIO et al., 2016; ALVES et al., 2016).

The study of the antifungal activity of the essential oil of Warionia saharae, rich in $(E)$ nerolidol (23.0\%) and linalool (15.2\%), on three apple rot fungi, Alternaria sp., Penicillium expansum, and Rhizopus stolonifer, showed mycelial growth inhibition at the concentration of $2.0 \mathrm{~mL} / \mathrm{L}$, demonstrating that the synergy between these major compounds was not the main responsible for the antifungal activity due to the low values of PMGI at high concentrations of this essential oil (ZNINI et al., 2013).

The essential oil of Thymus zygis, rich in geraniol (19.8\%) and linalool (30.0\%), showed antifungal activity against Candida spp., Aspergillus spp., and Cryptococcus neoformans; geraniol had a MIC between 0.32 and $0.64 \mathrm{~mL} / \mathrm{L}$, and an MFC between 0.64 and $125 \mathrm{~mL} / \mathrm{L}$ ); and linalool had a MIC between 0.64 and $125 \mathrm{~mL} / \mathrm{L}$ and an $\mathrm{MFC}$ between 2.5 and $5.0 \mathrm{~mL} / \mathrm{L}$ ) (GONÇALVES et al., 2010). However, the essential oil of Cinnamomum osmophloeum, which contains $90.6 \%$ of linalool, showed low antifungal activity, with values between $0-25 \%$ mycelial growth inhibition against Rhizoctonia solani, F. oxysporum, Ganoderma australe, F. solani, C. gloeosporioides, and Pestalotiopsis funereal.

The biological study with linalool alone revealed a low percentage of mycelial growth inhibition against these microorganisms, which evidences the importance of combined studies on the other major compounds and/or minor compounds, aiming at their synergistic action (LEE et al., 2005).

Marei et al. (2012) evaluated the antifungal activity using the technique of mycelial growth inhibition of four phytopathogenic fungi (Rhizoctonia solani, F. oxysporum, Penicillium Digitatum, and Aspergillus niger), where geraniol caused effective mycelial growth inhibition of 73.9\%. Shin and Lim (2004) studied the effect of geraniol on Trichophyton spp., reaching MIC values from 0.3 to $1.0 \mathrm{~mL} / \mathrm{L}$ and $\mathrm{MFC}$ from 0.5 to 2.0 $\mathrm{mL} / \mathrm{L}$.

Lee et al. (2008) reported the antifungal activity of commercial essential oils of 11 species of the family Myrtaceae on the phytopathogenic fungi
Phytophthora cactorum, Cryponectria parasitica, and $F$. circinatum and reported mycelial inhibition values ranging from 31.9 to $68.9 \%$ for citronellol, neral, and geranial, and a PMGI of $100 \%$ for geraniol on $P$. cactorum, at the concentration of 0.3 $\mathrm{mL} / \mathrm{L}$.

Citral (3,7-dimethyl-2,6-octadienal) is a mixture of two isomeric acyclic monoterpene aldehydes, geranial ( $E$-citral) and neral (Z-citral) (SADDIQ et al., 2010). The antifungal activity against the microorganisms evaluated in this work may be related to the high reactivity of the carbonyl grouping of the $\mathrm{Z} / \mathrm{E}$ isomers. Recent studies have demonstrated the efficacy of this compound as an antifungal agent, and it has been used against the causative agent of post-harvest diseases in Citrus sp, such as green mold (Penicillium digitatum), sour rot (Geotrichum citri-aurantii), and blue mold (Penicillium italicum) (SADDIQ et al., 2010; ZHENG et al., 2015, ZHOU et al., 2014; TAO et al., 2014).

Sampaio et al. (2016) reported citral as one of the major compounds of the essential oil of $M$. ovata leaves (68.5\%), which completely inhibited the fungus $F$. solani, causing its mortality at concentrations from $0.5 \mathrm{~mL} / \mathrm{L}$. Studies suggest that citral is responsible for the modification in the mitochondrial morphology and the cellular wall function of these phytopathogens, causing a decrease in the $\mathrm{O}_{2}$ level and respiratory rate and, consequently, leading to an increase in the permeability of the fungal membrane on the cell wall.

Sampaio et al. (2016) reported the antifungal activity of the essential oil of a Myrcia ovata chemotype (MYRO-006) with $58.27 \%$ of $(E)$ nerolidol, which showed $47.50 \%$ mycelial growth inhibition against F.solani. The alcohol (E)nerolidol, present as a major compound in the essential oil of Piper chaba Hunter (5.1\%), showed activity against the fungi Rhizoctonia solani, Botrytis cinerea, $F$. solani, $F$. oxysporum, Sclerotinia sclerotiorum, and Phytophthora capsici, causative agents of plant diseases, with minimum inhibitory concentrations between 125 and $500 \mu \mathrm{L}$ $\mathrm{mL}^{-1}$ (RAHMAN et al., 2011). This sesquiterpene alcohol was tested alone and showed biological activity against Trichophyton mentagrophytes, causing a change in the fungal morphology from the concentration of $0.4 \mu \mathrm{L} \mathrm{mL}{ }^{-1}$. Those results confirm that the antifungal activity of this compound is more pronounced in its isolated form (PARK et al., 2009).

The antifungal activity of the essential oils of all chemotypes evaluated in this study (except for MYRO-175, whose essential oil was more active 
than one of its major compounds, linalool) may be related to different combinations of the contents of their major and minor compounds. The essential oils of the chemotypes MYRO-175, MYRO-165, and MYRO-015 had nerolic acid at concentrations of $52.61 \%, 47.20 \%$, and $31.65 \%$, respectively, as one of their major compounds. Sampaio 2016 reported the isolation of nerolic acid and the antifungal activity on F.solani, F.pallidoroseum, and C.musae, proving that this biocompound is responsible for the pronounced antifungal activity of the essential oil of the chemotype MYRO-160, which presents a $69.44 \%$ of this acid.

Thus, results suggest that the combined synergic action between major and/or minor compounds in the complexity of the chemical composition of their essential oils may be related to their significant activity against the tested fungi. Therefore, the compounds found in larger and/or smaller amounts play an important role in these microorganisms, confirming the importance of synergism or antagonism between bioactive compounds of plant volatiles (LANGEVELD et al., 2014).

The essential oil of the tested chemotypes was more effective than their major compounds against $F$. pallidoroseum. For $C$. musae, the major compounds geraniol, found in the plant MYRO-156 $(74.37 \%)$, and citral were more effective than their respective essential oils. Conversely, $(E)$-nerolidol and geraniol of the chemotype MYRO-015 $(33.15 \%)$ were responsible for the antifungal activity of the essential oils of their respective chemotypes. Results propose that the mechanism of action of the samples tested against the phytopathogenic fungi sometimes acted on the principle of synergism and, in other moments, on the antagonism principle (KHAN et al., 2011).

Results indicate that the essential oil or its major compound showed different toxicity to both fungi tested. The essential oil was more toxic to $C$. musae, and the pure major compounds effectively inhibited $F$. pallidoroseum. This fact proves that the principle of action of the essential oils is different among microorganisms (bacteria, fungi, insects, mites). Thus, the study of the possible mechanisms of action of these compounds is fundamental to the development of new bioproducts.

\section{ACKNOWLEDGMENTS}

This study was financed in part by the Conselho Nacional de Desenvolvimento Científico e Tecnológico - Brasil (CNPq), the Fundação de Apoio à Pesquisa e a Inovação Tecnológica do Estado de Sergipe (Fapitec/SE) - Brasil, the Coordenação de Aperfeiçoamento de Pessoal de Nível Superior - Brasil (CAPES - Finance Code 001), the Financiadora de Estudos e Projetos - Brasil (FINEP).

RESUMO: No presente trabalho avaliou-se a atividade antifúngica de óleos essenciais de quimiotipos de Myrcia lundiana (MYRO-175, MYRO-156, MYRO-154, MYRO-165, and MYRO-015) e seus compostos majoritários (linalol, geraniol, citral e (E)-nerolidol) sobre os fungos fitopatogênicos Fusarium pallidoroseum (causa podridão em frutos de melão) e Colletotrichum musae (causa antracnose em frutos de banana). Os óleos essenciais foram obtidos hidrodestilação e analisados por CGEM/DIC. Para avaliação da atividade antifúngica foram testados os óleos essenciais e os compostos majoritários nas concentrações: 0,$1 ; 0,3 ; 0,4 ; 0,5 ; 0,7 ; 1,0$; 3,0 e 5,0 mL/L. Os principais compostos presentes nos óleos essenciais foram o ácido nerólico, o linalol, o geraniol, o citral e o $(E)$-nerolidol. Os óleos essenciais das plantas MYRO-154, MYRO-165 e MYRO-015 apresentaram CIM de $0,3 \mathrm{~mL} / \mathrm{L}$ e a planta MYRO-015 apresentou a menor concentração fungicida mínima (CFM) (1,0 mL/L). O geraniol e o citral foram os compostos que apresentaram o menor valor de CFM, 0,5 $\mathrm{mL} / \mathrm{L}$, frente aos dois fungos testados. $\mathrm{O}$ óleo essencial dos quimiotipos testados foram mais promissores que seus componentes majoritários puros, frente o $F$. pallidoroseum. Já para o C. musae, os componentes majoritários geraniol do quimiotipo MYRO-156 (74,37\%) e o citral foram mais promissores que seus respectivos óleos essenciais. Já o $(E)$-nerolidol e o geraniol do quimiotipo MYRO-015 (33,15\%) foram os responsáveis pela atividade antifúngica apresentada pelos óleos essenciais dos respectivos quimiotipos.

PALAVRAS-CHAVE: Myrcia ovata. Compostos voláteis. Fusarium pallidoroseum. Colletotrichum musae.

\section{REFERENCES}


ADAMS, R. P. Identification of essential oil components by gas chromatography/mass spectroscopy. 4th ed., Allured: Carol Stream, 2007. 804p.

ALVES, M.F.; NIZIO, D.A.C.; SAMPAIO, T.S.; NASCIMENTO JUNIOR, A.F; BRITO, F.A.; MELO, J.O.; ARRIGONI-BLANK, M.F.; GAGLIARDI, P.R.; MACHADO, S.M.F.; BLANK, A.F. Myrcia lundiana Kiaersk native populations have different essential oil composition and antifungal activity against Lasiodiplodia theobromae. Industrial Crops and Products, v. 85, p. 266-273, july. 2016. http//doi.org/10.1016/j.indcrop.2016.03.039

BAKKALI, F.; AVERBECK, D.; IDAOMAR, M. Biological effects of essential oils - A review. Food and Chemical Toxicology, USA, v. 46, n. 2, p. 446-475, fev. 2008. http//doi.org/10.1016/j.fct.2007.09.106

BLANK, A.F.; SAMPAIO, T.S.; NIZIO, D.A.C.; GAGLIARDI, P.R.; SILVA, F.L.S.; WISNIEWSKI JR, A.; ARRIGONI-BLANK, M.F.; ALVES, M.F.; MELO, J.O.; FEITOSA, R.B.; ALMEIDA, C.S.; NUNES, R.S.; LIMA, A.D.; WHITE, L.A.S. Formulação fungicida, método para controlar ou eliminar o fitopatógeno Lasiodiplodia theobromae à base do óleo essencial de Myrcia ovata Cambessedes. BR-10-2015-027461-0, Instituto Nacional da Propriedade Industrial: Rio de Janeiro, 2015.

BOUBAKER, H.; KARIM, H.; EL HAMDAOUI A.; MSANDA F.; LEACH D.; BOMBARDA, I.; VANLOOT, P.; ABBAD, A.; BOUDYACH, E.H.; AOUMAR, A.A.B. Chemical characterization and antifungal activities of four Thymus species essential oils against postharvest fungal pathogens of citrus. Industrial Crops and Products, v. 86, p. 95-101, Aug. 2016. https://doi.org/10.1016/j.indcrop.2016.03.036

CÂNDIDO, C.S.; PORTELLA, C.S.A.; LARANJEIRA, B.J.; SILVA, S.S.; ARRIAGA, A.M.C.; SANTIAGO, G.M.P.; GOMES, G.A.; ALMEIDA, P.C.; CARVALHO, C.B.M. Effects of Myrcia ovata Cambess. Essencial oil on planktonic growth of gastrointestinal microorganisms and biofilm formation of Enterococcus faecalis.

Brazilian Journal of Microbiology, São Paulo, v. 41, p. 621-627, oct. 2010. http://dx.doi.org/10.1590/S151783822010000300012

CHANG, H.T.; CHENG, Y.H.; WU, C.L.; CHANG, S.T.; CHANG, T.T.; SU, Y.C. Antifungal activity of essential oil and its constituents from Calocedrus macrolepis var, formosana florin leaf against plant pathogenic fungi. Bioresource Technology, v. 99, n. 14, p. 6266-6270, fev. 2008.

http//doi.org/10.1016/j.biortech.2007.12.005

EHLERT, P. A. D.; BLANK, A. F.; ARRIGONI-BLANK, M. F.; PAULA, J. W. A.; CAMPOS, D. A.; ALVIANO, C. S. Tempo de hidrodestilação na extração de óleo essencial de sete espécies de plantas medicinais. Revista Brasileira de Plantas Medicinais, Botucatu, v. 8, n. 2, p. 79-80, 2006.

GONÇALVES, M.J.; CRUZ, M.T.; CAVALEIRO, C.; LOPES, M.C. SALGUEIRO, L. Chemical, antifungal and cytotoxic evaluation of the essential oil of Thymus zygis subsp. sylvestris. Industrial Crops and Products, v. 32, p. 70-75, jul. 2010. https://doi.org/10.1016/j.indcrop.2010.03.005

GONDIM, D.M.F.; TERAO D.; MARTINS-MIRANDA, A.S.; VASCONCELOS, I.M.; OLIVEIRA, J.T.A. Benzo-thiadiazole-7-carbothioic acid S-methyl ester does not protect melon fruits against Fusarium pallidoroseum infection but induces defense responses in melon seedlings. Journal of Phytopathology, v. 156, p. 607-614, jun. 2008. https://doi.org/10.1111/j.1439-0434.2008.01419.x

KHAN, M.S.A.; AHMAD, I. Antifungal activity of essential oils and their synergy with fluconazole against drug-resistant strains of Aspergillus fumigatus and Trichophyton rubrum. Applied Microbiology and Biotechnology, v. 90, n. 3, p.1083-1094, may. 2011. http://doi.org/10.1007/s00253-011-3152-3

KFOURY, M.; SAHRAOUI, A.L-H.; BOURDON, N.; LARUELLE, F.; FONTAINE, J.; AUEZOVA, L.; GREIGE-GERGES, H.; FOURMENTIN, S. Solubility, photos tability and antifungal activity of phenylpropanoids encapsulated in cyclodextrins. Food Chemistry, v. 196, n. 1, p.518-525, Apr. 2016. https://doi.org/10.1016/j.foodchem.2015.09.078 
LANGEVELD, W.T.; VELDHUIZEN, E.J.A.; BURT, S.A. Synergy between essential oil components and antibiotics: a review. Critical Reviews in Microbiology, v. 40, n. 1, p. 76-94, fev. 2014. https://doi.org/10.3109/1040841X.2013.763219

LEE, H-C.; CHENG, S-S.; CHANG, S-T. Antifungal property of the essential oils and their constituents from Cinnamomum osmophloeum leaf against tree pathogenic fungi. Journal of the Science of Food and Agriculture, v.85, p. 2047-2053, jun. 2005. https://doi.org/10.1002/jsfa.2216

LEE, Y-S.; KIM, J.; SHIN, S-C.; LEE, S-G.; PARK, I-K. Antifungal activity of Myrtaceae essential oils and their components against three phytopathogenic fungi. Flavour and Fragrance Journal, v. 23, p. 23-28, jan, 2008. https://doi.org/10.1002/ffj.1850

LIMA, M.A.A., OLIVEIRA, F.F.M., GOMES, G.A., L, LAVOR, P.L., SANTIAGO, G.M.P., DIAS, A.T.N., ARRIAGA., A.M.C., LEMOS, T.L.G., CARVALHOS, M.G. Evaluation of larvicidal activity of the essential oils of plants species from Brazil against Aedes aegypti (Diptera: Culicidae). African Journal of Biotechnology, v. 10, n. 55, p. 11716-11720, sept. 2011. https://doi.org/10.5897/AJB11.1102

LOKESH, S.; GOVINDAPPA, M.; RAGHAVENDRA, V.; SUDISHA. First report on the flower-rot of Crossandra infundibuliformis, a commercial flower crop in India. Journal of General Plant Pathology, v. 74, p. 338-340, aug. 2008. https://doi.org/10.1007/s 10327-008-0101-9

MAREI, G.I.KH.; RASOUL, M.A.A.; ABDELGALEIL, S.A.M. Comparative antifungal activities and biochemical effects of monoterpenes on plant pathogenic fungi. Pesticide Biochemistry and Physiology, v. 103, n. 1, p. 56-61, may. 2012. https://doi.org/10.1016/j.pestbp.2012.03.004

PARK, M.J.; GWAK, K.S.; YANG, I.; KIM, K.W.; JEUNG, E.B.; CHANG, J.W.; CHOI, I.G. Effect of citral, eugenol, nerolidol and $\alpha$-terpineol on the ultrastructural changes of Trichophyton mentagrophytes. Fitoterapia, v. 80, n. 5, p. 290-296, jul. 2009. https://doi.org/10.1016/j.fitote.2009.03.007

PESSOA, W.R.L.S.; OLIVEIRA, S.M.A.; DANTAS, S.A.F.; TAVARES, S.C.C.; DE H., SANTOS, A.M.G. Efeito da temperatura e período de molhamento sobre o desenvolvimento de lesões de Colletotrichum musae em banana. Summa Phytopathologica, Botucatu, v. 33, n. 2, p.147-151, nov. 2007. http://org/10.1590/S010054052007000200008

QUINTANS-JÚNIOR L.J.; GUIMARÃES, A.G.; SANTANA, M.T.; ARAÚJO, B.E.S.; MOREIRA, F.V.; BONJARDIM, L.R.; ARAÚJO, A.A.S.; SIQUEIRA, J.S.; ANTONIOLLI, Â.R.; BOTELHO, M.A.;

ALMEIDA, J. R. G. S.; SANTOS, M.R.V. Citral reduces nociceptive and inflammatory response in rodents.

Revista Brasileira de Plantas Medicinais, Curitiba, v. 21, n. 3, p. 497-502, jun. 2011.

http://dx.doi.org/10.1590/S0102-695X2011005000065

RAHMAN, A.; AL-REZA, S.M.; KANG, S.C. Antifungal activity of essential oil and extracts of Piper chaba Hunter against phytopathogenic fungi. Journal of the American Oil Chemists' Society, v. 88, p. 573-579, apr. 2011. http://dx.doi.org/10.1007/s11746-010-1698-3

SADDIQ, A.A.; KHAYYAT, S.A. Chemical and antimicrobial studies of monoterpene: Citral. Pesticide Biochemistry and Physiology, v. 98, p. 89-93, sept. 2010. https://doi.org/10.1016/j.pestbp.2010.05.004

SAMPAIO, T.S.; NIZIO, D.A.C.; WHITE, L.A.S.; MELO, J.O.; ALMEIDA, C.S.; ALVES, M. F.; GAGLIARDI, P.R.; ARRIGONI-BLANK, M.F.; WISNIEWSKI JR, A.; SOBRAL, M.E. G.; BLANK, A.F. Chemical diversity of a wild population of Myrcia ovata Cambessedes and antifungal activity against Fusarium solani. Industrial Crops and Products, v. 86, p. 196-209, aug. 2016.

https://doi.org/10.1016/j.indcrop.2016.03.042 
SANTOS, G.C.M.; GOMES, G.A.; GONÇALVES, G.M.; SOUSA, L.M.; SANTIAGO, G.M.P.; CARVALHO, M.G.; MARINHO, B.G. Essential oil from Myrcia ovata: chemical composition, antinoceptive and antiinflamatory properties in mice. Planta Médica, v. 80, p. 1588-1596, Aug, 2014. https://doi.org/10.1055/s0034-1383120

SHIN, S.; LIM, S. Antifungal effects of herbal essential oils alone and in combination with ketoconazole against Trichophyton spp. Journal of Applied Microbiology, v. 97, n.1, p. 1289-1296, sept. 2004. https://doi.org/10.1111/j.1365-2672.2004.02417.x

TAO, N.; OUYANG, Q.; JIA, L. Citral inhibits mycelial growth of Penicillium italicum by a membrane damage mechanism. Food Control, v. 41, p. 116-121, jul. 2014. https://doi.org/10.1016/j.foodcont.2014.01.010

ZHENG, S.; JING, G.; WANG, X.; OUYANG, Q.; JIA, L.; TAO, N. Citral exerts its antifungal activity against Penicillium digitatum by affecting the mitochondrial morphology and function. Food Chemistry, v. 178, p. 7681, jul. 2015. https://doi.org/10.1016/j.foodchem.2015.01.077

ZHOU, H.; TAO, N.; JIA, L. Antifungal activity of citral, octanal and $\alpha$-terpineol against Geotrichum citriaurantii. Food Control, v. 37, p. 277-283, mar. 2014. https://doi.org/10.1016/j.foodcont.2013.09.057

ZNINI, M.; CRISTOFARI, G.; MAJIDI, L.; EL HARRAK, A.; PAOLINI, J.; COSTA, J. In vitro antifungal activity and chemical composition of Warionia saharae essential oil against 3 apple phytopathogenic fungi. Food Science and Biotechnology, v. 22, p. 113-119, 2013. https://doi.org/10.1007/s10068-013-0056-2 